\title{
BENTUK REGISTER PADA IKLAN PROPERTI DALAM SITUS JUAL BELI ONLINE OLX
}

\author{
Rizqi Hidayatulloh ${ }^{1}$, Tri Pujiati ${ }^{2}$ \\ Universitas Pamulang, Tangerang Selatan, Indonesia ${ }^{12}$ \\ hidayatulloh.rizqi24@gmail.com ${ }^{1}$,dosen00356@unpam.ac.id ${ }^{2}$
}

\begin{abstract}
Abstrak
Penelitian ini bertujuan untuk mendeskripsikan bentuk register pada iklan properti di media online OLX. Penelitian ini menggunakan metode deskriptif kualitatif dengan pendekatan sosiolinguistik. Data diperoleh melalui media online OLX dengan memfokuskan pada bentuk register yang terdapat pada iklan ptroperti. Data dipilih dengan menggunakan metode purposive sampling sehingga dapat mewakili jumlah data. Hasil penelitian ini menunjukkan bahwa register yang terdapat pada kategori iklan properti dapat dikelompokkan berdasarkan bentuk tunggal sebanyak 27 register atau sebesar 52,94\%. Berdasarkan bentuknya, diperoleh 24 register dalam bentuk kompleks atau sebesar $47,06 \%$, bentuk kompleks terdiri dari afiksasi sebanyak 3 register dan abreviasi sebanyak 21 register. Hasil penelitian menunjukkan bahwa register yang dimiliki oleh masing-masing iklan properti bervariasi sesuai dengan fungsinya masing-masing dan sesuai dengan ragam bahasa yang digunakan dalam iklan.
\end{abstract}

Kata kunci : Sosiolinguistik, Ragam Bahasa dan Register.

\section{Pendahuluan}

Untuk mengungkapkan atau mengutarakan isi pikiran dan perasaannya, manusia dapat melakukan melalui dua cara, yaitu secara lisan dan tulisan. Kedua cara ini disebut sebagai ragam lisan dan ragam tulis. Komunikasi dengan cara lisan terlihat ketika penutur bersemuka dengan mitra tuturnya, dan kadang disertai gerakan atau isyarat tertentu yang membuat mitra tutur semakin jelas terhadap apa yang disampaikan penutur (Moeliono, 1998: 7), sedangkan dalam ragam tulis penutur dan mitra tuturnya tidak berhadapan langsung, sehingga penulis harus terang dan jelas dalam mengungkapkan maksudnya. Bahasa yang digunakan haruslah bahasa yang 
dapat dipahami oleh mitra tuturnya dalam hal ini pembaca. Demikian juga, kata-kata yang digunakan harus tepat agar apa yang dimaksud oleh penulis dapat dipahami dengan benar oleh pembaca.

Dunia semakin cepat berubah, dalam dua dasa warsa terakhir perkembangan teknologi sudah demikian pesatnya memberikan dampaknya yang menyentuh segala aspek kehidupan manusia. Salah satu hal yang berkembang sangat pesat dan menjadi pemicu dari perkembangan yang ada adalah komunikasi. Salah satu pengguna bahasa dalam iklan adalah OLX. OLX merupakan pasar iklan baris online lokal yang dapat diakses melalui internet dan juga melalui aplikasi pada ponsel.

Terkait dengan hal tersebut, penulis tertarik untuk menganalisis register iklan propertidalam situs jual beli online OLX. Hal ini penting untuk dilakukan karena pemakaian bahasa dalam iklan property tersebut dapat menimbulkan pemahaman yang berbeda-beda pada setiap pembaca iklan tersebut

\section{Metode Penelitian}

Pada penelitian ini penulis menggunakan metode deskriptif kualitatif. Teknik penelitian yang digunakan adalah teknik deskriptif kualitatif. Menurut Bagdan dan Taylor (Moleong, 2007 : 31) penelitian kualitatif adalah penelitian yang menghasilkan data deskriptif, yaitu dari yang berupa kata-kata tertulis / lisan dari orang-orang atau perilaku yang diamati.

\section{Pembahasan}

\section{Bentuk Register Pada Iklan Properti}

Berdasarkan data temuan register diperoleh sebanyak 51 register pada kategori properti. Berdasarkan bentuknya register pada kategori properti dalam situs jual beli online OLX dapat dilihat pada tabel 4.4 dibawah ini. 
Tabel 1

Bentuk Register Pada Kategori Properti

\begin{tabular}{|c|c|c|c|c|}
\hline \multirow{2}{*}{$\begin{array}{c}\text { NOMOR } \\
\text { DATA }\end{array}$} & \multicolumn{2}{|c|}{ REGISTER } & \multicolumn{2}{|c|}{ BENTUK } \\
\hline & NO REG & REGISTER & $\begin{array}{c}\text { TUNGGA } \\
\text { L }\end{array}$ & $\begin{array}{c}\text { KOMPLEK } \\
\text { S }\end{array}$ \\
\hline D-P 001 & $\mathrm{R}-055$ & SHM & & Abreviasi \\
\hline \multirow{2}{*}{ D-P 002} & $\mathrm{R}-056$ & $\mathrm{BR}$ & & Abreviasi \\
\hline & $\mathrm{R}-057$ & $\mathrm{Lt}$ & & Abreviasi \\
\hline \multirow{4}{*}{ D-P 003} & $\mathrm{R}-058$ & $\mathrm{LT}$ & & Abreviasi \\
\hline & R-059 & LB & & Abreviasi \\
\hline & R-060 & HGB & & Abreviasi \\
\hline & R-061 & Feet & Tunggal & \\
\hline \multirow{2}{*}{ D-P 004} & $\mathrm{R}-062$ & TP & & Abreviasi \\
\hline & R-063 & Nego & Tunggal & \\
\hline \multirow{4}{*}{ D-P 005} & R-064 & Minimalis & Tunggal & \\
\hline & R-065 & Semi Furnished & Tunggal & \\
\hline & R-066 & $\mathrm{BU}$ & & Abreviasi \\
\hline & R-067 & DP & & Abreviasi \\
\hline \multirow{3}{*}{ D-P 006} & R-068 & Promo & Tunggal & \\
\hline & R-069 & Carport & Tunggal & \\
\hline & $\mathrm{R}-070$ & Flat & Tunggal & \\
\hline \multirow{5}{*}{ D-P 007} & R-071 & 2 Pintu & Tunggal & \\
\hline & R-072 & $\mathrm{SS}$ & & Abreviasi \\
\hline & $\mathrm{R}-073$ & Minat & Tunggal & \\
\hline & R-074 & Tlp & & Abreviasi \\
\hline & $\mathrm{R}-075$ & Nego Keras & Tunggal & \\
\hline \multirow{3}{*}{ D-P 008} & R-076 & Row & Tunggal & \\
\hline & R-077 & KT & & Abreviasi \\
\hline & R-078 & KM & & Abreviasi \\
\hline \multirow{6}{*}{ D-P 009} & R-079 & Exterior & Tunggal & \\
\hline & R-080 & Sanitair & Tunggal & \\
\hline & $\mathrm{R}-081$ & Pantek & Tunggal & \\
\hline & $\mathrm{R}-082$ & AJB & & Abreviasi \\
\hline & $\mathrm{R}-083$ & Sudah Pecah & Tunggal & \\
\hline & R-084 & Balik Nama & Tunggal & \\
\hline \multirow{3}{*}{ D-P 010} & $\mathrm{R}-085$ & BPHTB & & Abreviasi \\
\hline & R-086 & Cash & Tunggal & \\
\hline & R-087 & IMB & & Abreviasi \\
\hline
\end{tabular}




\begin{tabular}{|c|c|c|c|c|}
\hline & R-088 & Ready Stock & Tunggal & \\
\hline \multirow{3}{*}{ D-P 011} & R-089 & Tumbak & Tunggal & \\
\hline & R-090 & Gan & & Abreviasi \\
\hline & R-091 & Hub & & Abreviasi \\
\hline \multirow{4}{*}{ D-P 012} & R-092 & HA & & Abreviasi \\
\hline & R-093 & Owner & Tunggal & \\
\hline & R-094 & Closing & Tunggal & \\
\hline & R-095 & SHGB & & Abreviasi \\
\hline \multirow{4}{*}{ D-P 013} & R-096 & Dibawah pasar & & Afiksasi \\
\hline & R-097 & Harga pasar & Tunggal & \\
\hline & R-098 & Lebar muka & Tunggal & \\
\hline & R-099 & Cluster & Tunggal & \\
\hline D-P 014 & $\mathrm{R}-100$ & Are & Tunggal & \\
\hline D-P 015 & R-101 & Petakan & & Afiksasi \\
\hline \multirow{2}{*}{ D-P 016} & R-102 & Over kredit & Tunggal & \\
\hline & $\mathrm{R}-103$ & Take over & Tunggal & \\
\hline D-P 017 & R-104 & Kosongan & & Afiksasi \\
\hline D-P 018 & R-105 & Kurleb & & Abreviasi \\
\hline
\end{tabular}

Berdasarkan tabel 1, diperoleh data sebanyak 51 register pada kategori iklan properti yang dapat dikategorikan ke dalam bentuk tunggal dan bentuk kompleks. Berdasarkan bentuk register, register kategori iklan properti diperoleh bentuk tunggal sebanyak 27 register atau sebesar 52,94\%. Berdasarkan bentuknya, diperoleh 24 register dalam bentuk kompleks atau sebesar $47,06 \%$, bentuk kompleks terdiri dari afiksasi sebanyak 3 register dan abreviasi sebanyak 21 register.

Berikut ini analisis register iklan pada kategori iklan properti.

\section{D-P 001}

Pada data R-055 terdapat register SHM. Secara bentuk register SHM masuk ke dalam bentuk kompleks, terjadi proses morfologis yaitu abreviasi berupa singkatan dari kata setifikat hak milik. Istilah SHM secara sosial sudah dapat dipahami oleh masyarakat umum terutama dalam hal ini pembaca iklan. Penggunaan Register SHM masuk ke dalam ragam santai. 


\section{D-P 002}

Pada data R-056 terdapat register $B R$. Istilah $B R$ secara bentuk masuk ke dalam bentuk kompleks, $B R$ merupakan akronim dari kata bedroom yang dalam bahasa indonesia berarti kamar tidur, register ini mengalami proses morfologis yaitu abreviasi. Secara sosial istilah ini termasuk dalam ragam santai, seperti yang kita lihat dalam data, istilah ini digunakan dalam proses komunikasi antara penjual dan pembeli.

Pada data R-057 terdapat register $L t$. Secara bentuk istilah $L t$ masuk ke dalam bentuk kompleks, terjadi proses morfologis berupa abreviasi. Register $L t$ berasal dari kata Lantai. Istilah $L t$ sering digunakan dalam transaksi jual beli properti yang secara sosial istilah ini masuk ke dalam ragam santai.

\section{D-P 003}

Pada data R-058 terdapat register $L T$. Berdasarkan bentuk, istilah $L T$ termasuk ke dalam bentuk kompleks, terjadi proses morfologis yaitu abreviasi berupa singkatan dari kata Luas Tanah. Istilah $L T$ secara sosial sudah dapat dipahami oleh masyarakat umum terutama dalam hal ini pembaca iklan. Register $L T$ secara sosial masuk ke dalam penggunaan ragam santai.

Pada data R-059 terdapat register $L B$. Berdasarkan bentuk, istilah $L B$ termasuk ke dalam bentuk kompleks, terjadi proses morfologis berupa abreviasi. $L B$ merupakan singkatan dari Luas Bangunan. Secara sosial istilah $L B$ merupakan istilah yang sering digunakan dalam komunikasi antara penjual dan pembeli yang yang secara sosial termasuk ke dalam ragam santai, seperti yang kita temukan dalam data.

Pada data R-060 terdapat register $H G B$. Berdasarkan bentuk, istilah $H G B$ termasuk ke dalam bentuk kompleks, terjadi proses morfologis berupa abreviasi. $H G B$ merupakan singkatan dari Hak Guna Bangunan. Secara sosial istilah $H G B$ merupakan istilah yang sering digunakan dalam komunikasi antara penjual dan pembeli yang yang secara sosial termasuk ke dalam ragam santai, seperti yang kita temukan dalam data. 
Pada data R-061 terdapat register feet. Istilah ini sering digunakan dalam iklan pada situs jual beli online OLX untuk menjelaskan kondisi barang yang dijualnya, secara sosial register ini masuk ke dalam ragam santai. Berdasarkan bentuk istilah feet merupakan bentuk tunggal yang tidak mengalami proses morfologis.

\section{D-P 004}

Pada data R-062 terdapat register $T P$. Berdasarkan bentuk, istilah $T P$ termasuk ke dalam bentuk kompleks, terjadi proses morfologis yaitu abreviasi. Register $T P$ merupakan singkatan dari kata Tanpa Perantara. Istilah TP secara sosial sudah dapat dipahami oleh masyarakat umum terutama dalam hal ini pembaca iklan. Register TP secara sosial masuk ke dalam ragam santai.

Pada data R-063 terdapat register nego. Istilah ini sering digunakan dalam iklan pada situs jual beli online OLX untuk menawarkan harga jual barang dalam iklannya, secara sosial register ini masuk ke dalam ragam santai. Berdasarkan bentuk istilah nego merupakan bentuk tunggal yang tidak mengalami proses morfologis.

\section{D-P 005}

Pada data R-064 terdapat register minimalis. Istilah minimalis secara bentuk masuk ke dalam bentuk tunggal, yang tidak mengalami proses morfologis. Secara sosial istilah minimalis merupakan istilah yang sering digunakan dalam transaksi jual beli properti dan masuk ke dalam ragam santai.

Pada data R-065 terdapat register semi furnished. Register semi furnished secara bentuk masuk ke dalam bentuk tunggal, yang tidak mengalami proses morfologis. Secara sosial istilah semi furnished merupakan istilah yang sering digunakan oleh penjual dalam iklannya, yang dalam hal ini properti. Register ini secara sosial masuk ke dalam ragam santai.

Pada data R-066 terdapat register $B U$. Berdasarkan bentuk, istilah $B U$ termasuk ke dalam bentuk kompleks, terjadi proses morfologis yaitu abreviasi. Register $B U$ merupakan singkatan dari kata Butuh Uang. Istilah $B U$ secara sosial 
sudah dapat dipahami oleh masyarakat umum terutama dalam hal ini pembaca iklan. Register $B U$ secara sosial masuk ke dalam ragam santai.

Pada data R-067 terdapat register $D P$. Istilah $D P$ secara bentuk masuk ke dalam bentuk kompleks, DP merupakan singkatan dari Dana Pertama yang mengalami proses morfologis yaitu abreviasi. Secara sosial istilah ini termasuk dalam ragam santai, seperti yang kita lihat dalam data, istilah ini digunakan dalam proses komunikasi oleh penjual dalam iklannya.

\section{D-P 006}

Pada data R-068 terdapat register promo. Register promo secara bentuk masuk ke dalam bentuk tunggal, yang tidak mengalami proses morfologis. Secara sosial istilah promo merupakan istilah yang sering digunakan dalam transaksi jual beli dan masuk ke dalam ragam santai.

Pada data R-069 terdapat register carport. Istilah carport secara bentuk masuk ke dalam bentuk tunggal, yang tidak mengalami proses morfologis. Secara sosial istilah carport merupakan istilah yang sering digunakan dalam transaksi jual beli properti dalam bahasa indonesia berarti tempat menyimpan kendaraan. Register ini masuk ke dalam ragam santai.

Pada data R-070 terdapat register flat. Istilah flat secara bentuk masuk ke dalam bentuk tunggal, yang tidak mengalami proses morfologis. Secara sosial istilah flat merupakan istilah yang sering digunakan dalam transaksi jual beli, register ini masuk ke dalam ragam santai.

\section{D-P 007}

Pada data R-071 terdapat register 2 pintu. Berdasarkan bentuk, istilah 2 pintu termasuk ke dalam bentuk tunggal, yang tidak mengalami proses morfologis. Secara sosial istilah 2 pintu merupakan istilah yang sering digunakan dalam transaksi jual beli properti, register 2 pintu termasuk ke dalam penggunaan ragam santai. 
Pada data R-072 terdapat register SS. Istilah SS secara bentuk masuk ke dalam bentuk kompleks, SS merupakan singkatan dari Surat Surat yang mengalami proses morfologis yaitu abreviasi. Secara sosial istilah ini termasuk dalam ragam santai, seperti yang kita lihat dalam data, istilah ini digunakan dalam proses komunikasi oleh penjual dalam iklannya.

Pada data R-073 terdapat register minat. Berdasarkan bentuk, istilah minat termasuk ke dalam bentuk tunggal, yang tidak mengalami proses morfologis. Secara sosial istilah minat merupakan istilah yang sering digunakan dalam transaksi jual beli properti, register minat termasuk ke dalam penggunaan ragam santai.

Pada data R-074 terdapat register Tlp. Secara bentuk istilah Tlp masuk ke dalam bentuk kompleks, terjadi proses morfologis berupa abreviasi. Register Tlp berasal dari kata Telepon. Istilah Telepon sering digunakan dalam transaksi jual beli properti yang secara sosial istilah ini masuk ke dalam ragam santai.

Pada data R-075 terdapat register nego keras. Berdasarkan bentuk, istilah nego keras termasuk ke dalam bentuk tunggal, yang tidak mengalami proses morfologis. Secara sosial istilah nego keras masuk ke dalam ragam santai, istilah nego keras sering digunakan penjual untuk menegaskan harga barang yang akan dijual, seperti yang kita temukan dalam data.

\section{D-P 008}

Pada data R-076 terdapat register row. Berdasarkan bentuk, register row termasuk ke dalam bentuk tunggal, yang tidak mengalami proses morfologis. Secara sosial istilah row masuk ke dalam ragam santai, istilah row sering digunakan penjual untuk menerangkan kondisi lebar jalan di rumah yang akan dijual, seperti yang kita temukan dalam data.

Pada data R-077 terdapat register $K T$. Istilah $K T$ secara bentuk masuk ke dalam bentuk kompleks, KT merupakan singkatan dari Kamar Tidur yang mengalami proses morfologis yaitu abreviasi. Secara sosial istilah ini termasuk dalam 
ragam santai, seperti yang kita lihat dalam data, istilah ini digunakan dalam proses komunikasi oleh penjual dalam iklannya.

Pada data R-078 terdapat register $K M$. Istilah $K M$ secara bentuk masuk ke dalam bentuk kompleks, $K M$ merupakan singkatan dari Kamar Mandi yang mengalami proses morfologis yaitu abreviasi. Secara sosial istilah ini termasuk dalam ragam santai, seperti yang kita lihat dalam data, istilah ini digunakan dalam proses komunikasi oleh penjual dalam iklannya.

\section{D-P 009}

Pada data R-080 terdapat register exterior. Berdasarkan bentuk, istilah exterior termasuk ke dalam bentuk tunggal, yang tidak mengalami proses morfologis. Secara sosial istilah exterior merupakan istilah yang sering digunakan dalam transaksi jual beli properti, register exterior termasuk ke dalam penggunaan ragam santai.

Pada data R-081 terdapat register sanitair. Berdasarkan bentuk, istilah sanitair termasuk ke dalam bentuk tunggal, yang tidak mengalami proses morfologis. Secara sosial istilah sanitair merupakan istilah yang sering digunakan dalam transaksi jual beli properti, register sanitair termasuk ke dalam penggunaan ragam santai.

Pada data R-082 terdapat register pantek. Berdasarkan bentuk, istilah pantek termasuk ke dalam bentuk tunggal, yang tidak mengalami proses morfologis. Secara sosial istilah pantek merupakan istilah yang sering digunakan dalam transaksi jual beli oleh penjual untuk menerangkan kondisi rumah yang akan dijualnya, register pantek termasuk ke dalam penggunaan ragam santai.

Pada data R-083 terdapat register $A J B$. Istilah $A J B$ secara bentuk masuk ke dalam bentuk kompleks, $A J B$ merupakan singkatan dari Akte Jual Beli yang mengalami proses morfologis yaitu abreviasi. Secara sosial istilah ini termasuk dalam ragam santai, seperti yang kita lihat dalam data, istilah ini digunakan dalam proses komunikasi oleh penjual dalam iklannya. 
Pada data R-084 terdapat register sudah pecah. Berdasarkan bentuk, istilah sudah pecah termasuk ke dalam bentuk tunggal, yang tidak mengalami proses morfologis. Secara sosial istilah sudah pecah merupakan istilah yang sering digunakan penjual untuk menerangkan kondisi rumah yang akan dijualnya, register sudah pecah termasuk ke dalam penggunaan ragam santai.

Pada data R-085 terdapat register balik nama. Berdasarkan bentuk, istilah balik nama termasuk ke dalam bentuk tunggal, yang tidak mengalami proses morfologis. Secara sosial istilah balik nama merupakan istilah yang sering digunakan dalam transaksi jual beli, register balik nama termasuk ke dalam penggunaan ragam santai.

\section{D-P 010}

Pada data R-086 terdapat register BPHTB. Istilah BPHTB secara bentuk masuk ke dalam bentuk kompleks, BPHTB merupakan singkatan dari Bea Perolehan Hak Tanah Bangunan yang mengalami proses morfologis yaitu abreviasi. Secara sosial istilah ini termasuk dalam ragam santai, seperti yang kita lihat dalam data, istilah ini digunakan dalam proses komunikasi oleh penjual dalam iklannya.

Pada data R-087 terdapat register cash. Berdasarkan bentuk, istilah cash termasuk ke dalam bentuk tunggal, yang tidak mengalami proses morfologis. Secara sosial istilah cash merupakan istilah yang sering digunakan dalam transaksi jual beli, register cash yang terdapat dalam data termasuk ke dalam penggunaan ragam santai.

Pada data R-088 terdapat register $I M B$. Register $I M B$ secara bentuk masuk ke dalam bentuk kompleks, $I M B$ merupakan singkatan dari Izin Mendirikan Bangunan yang mengalami proses morfologis yaitu abreviasi. Secara sosial istilah ini termasuk dalam ragam santai, seperti yang kita lihat dalam data, istilah ini digunakan dalam proses komunikasi oleh penjual dalam iklannya.

Pada data R-089 terdapat register ready stock. Istilah ini sering digunakan dalam iklan pada situs jual beli online OLX untuk menarik minat para pembaca iklan, secara sosial register ini masuk ke dalam ragam santai. Berdasarkan bentuk 
istilah ready stock merupakan bentuk tunggal yang tidak mengalami proses morfologis.

\section{D-P 011}

Pada data R-090 terdapat register tumbak. Berdasarkan bentuk, istilah tumbak termasuk ke dalam bentuk tunggal, yang tidak mengalami proses morfologis. Secara sosial istilah tumbak merupakan istilah yang sering digunakan dalam transaksi jual beli dalam hal ini jual beli properti, register tumbak yang terdapat dalam data termasuk ke dalam penggunaan ragam santai.

Pada data R-091 terdapat register gan. Secara bentuk register gan masuk ke dalam bentuk kompleks, terjadi proses abreviasi berupa penggalan. Register gan merupakan penggalan dari kata juragan yang sering digunakan dalam komunikasi jual beli. Secara sosial register ini masuk ke dalam ragam santai, istilah ini sering digunakan oleh penjual untuk menyapa calon pembeli.

Pada data R-092 terdapat register hub. Secara bentuk register hub masuk ke dalam bentuk kompleks, terjadi proses abreviasi berupa penggalan. Register hub merupakan penggalan dari kata hubungi yang sering digunakan dalam komunikasi jual beli. Secara sosial register ini masuk ke dalam ragam santai, istilah ini sering digunakan untuk menghubungi penjual.

\section{D-P 012}

Pada data R-093 terdapat register Ha. Secara bentuk register Ha masuk ke dalam bentuk kompleks, terjadi proses abreviasi berupa penggalan. Register $\mathrm{Ha}$ merupakan penggalan dari kata hektar. Secara sosial register ini masuk ke dalam ragam santai.

Pada data R-094 terdapat register owner. Berdasarkan bentuk, istilah owner termasuk ke dalam bentuk tunggal, yang tidak mengalami proses morfologis. Secara sosial istilah owner merupakan istilah yang sering digunakan dalam transaksi jual beli 
dalam hal ini jual beli properti, register owner yang terdapat dalam data termasuk ke dalam penggunaan ragam santai.

Pada data R-095 terdapat register closing. Istilah ini sering digunakan dalam iklan pada situs jual beli online OLX, secara sosial register ini masuk ke dalam ragam santai. Berdasarkan bentuk istilah closing merupakan bentuk tunggal yang tidak mengalami proses morfologis.

Pada data R-096 terdapat register SHGB. Register $S H G B$ secara bentuk masuk ke dalam bentuk kompleks, SHGB merupakan singkatan dari Sertifikat Hak Guna Bangunan yang mengalami proses morfologis yaitu abreviasi. Secara sosial istilah ini termasuk dalam ragam santai, seperti yang kita lihat dalam data, istilah ini digunakan dalam proses komunikasi oleh penjual dalam iklannya.

\section{D-P 013}

Pada data R-097 terdapat register dibawah pasar. Berdasarkan bentuk, istilah dibawah pasar termasuk ke dalam bentuk kompleks, terjadi proses morfologis yaitu afiksasi, terdapat prefiks di-. Kata ini sering digunakan dalam ragam santai antara penjual dan pembeli, untuk menjelaskan kondisi barang yang ditawarkan dalam iklan.

Pada data R-098 terdapat register harga pasar. Berdasarkan bentuk, istilah harga pasar termasuk ke dalam bentuk tunggal, yang tidak mengalami proses morfologis. Secara sosial istilah harga pasar merupakan istilah yang sering digunakan dalam transaksi jual beli dalam hal ini jual beli properti, register harga pasar yang terdapat dalam data termasuk ke dalam penggunaan ragam santai.

Pada data R-099 terdapat register lebar muka. Berdasarkan bentuk, istilah lebar muka termasuk ke dalam bentuk tunggal, yang tidak mengalami proses morfologis. Secara sosial istilah lebar muka merupakan istilah yang sering digunakan dalam transaksi jual beli dalam hal ini jual beli properti, register lebar muka yang terdapat dalam data termasuk ke dalam penggunaan ragam santai.

Pada data R-100 terdapat register cluster. Berdasarkan bentuk, istilah harga pasar termasuk ke dalam bentuk tunggal, yang tidak mengalami proses morfologis. 
Secara sosial istilah cluster merupakan istilah yang sering digunakan dalam transaksi jual beli untuk menerangkan rumah yang hendak ditawarkan, register cluster yang terdapat dalam data termasuk ke dalam penggunaan ragam santai.

\section{D-P 014}

Pada data R-101 terdapat register are. Berdasarkan bentuk, register are termasuk ke dalam bentuk tunggal, yang tidak mengalami proses morfologis. Secara sosial istilah are merupakan istilah yang sering digunakan dalam transaksi jual beli, register are yang terdapat dalam data termasuk ke dalam penggunaan ragam santai.

\section{D-P 015}

Pada data R-102 terdapat register petakan. Berdasarkan bentuk, istilah petakan termasuk ke dalam bentuk kompleks, terjadi proses morfologis yaitu afiksasi, terdapat sufiks -an. Istilah ini sering digunakan dalam ragam santai antara penjual dan pembeli, untuk menjelaskan kondisi barang yang ditawarkan dalam iklan.

\section{D-P 016}

Pada data R-103 terdapat register over kredit. Berdasarkan bentuk, istilah over kredit termasuk ke dalam bentuk tunggal, yang tidak mengalami proses morfologis. Secara sosial istilah over kredit merupakan istilah yang sering digunakan dalam transaksi jual beli untuk menerangkan properti yang hendak ditawarkan, register over kredit yang terdapat dalam data termasuk ke dalam penggunaan ragam santai.

Pada data R-104 terdapat register take over. Berdasarkan bentuk, istilah take over termasuk ke dalam bentuk tunggal, yang tidak mengalami proses morfologis. Secara sosial istilah take over merupakan istilah yang sering digunakan dalam transaksi jual beli untuk menerangkan rumah yang hendak ditawarkan, register take over yang terdapat dalam data termasuk ke dalam penggunaan ragam santai. 


\section{D-P 017}

Pada data R-105 terdapat register kosongan. Berdasarkan bentuk, istilah kosongan termasuk ke dalam bentuk kompleks, terjadi proses morfologis yaitu afiksasi, terdapat sufiks -an. Istilah ini sering digunakan dalam ragam santai antara penjual dan pembeli, untuk menjelaskan kondisi barang yang ditawarkan dalam iklan

\section{D-P 018}

Pada data R-106 terdapat register kurleb. Secara bentuk register kurleb masuk ke dalam bentuk kompleks, terjadi proses morfologis berupa abreviasi, istilah kurleb berasal dari kata "kurang” + ”lebih”. Istilah kurleb sering digunakan dalam iklan pada situs jual beli online OLX, secara sosial penggunaan register kurleb dalam iklan termasuk ke dalam ragam santai.

\section{Simpulan}

Berdasarkan pembahasan di atas, maka dapat disimpulkan bahwa berdasarkan bentuk register diperoleh bentuk tunggal, bentuk kompleks yang terdiri dari afiksasi, abreviasi dan pengulangan. Makna register pada situs jual beli online OLX terbagi menjadi tiga jenis yaitu makna leksikal, makna gramatikal dan makna kontekstual. Register pada situs jual beli online OLX merupakan bentuk variasi kebahasaan, ciri keragaman bahasa yang akan terus berkembang dengan kemungkinan bertambahnya istilah-istilah baru yang lainnya.

\section{Daftar Pustaka}

Chaer, Abdul dan Leonie, Agustina. 2004. Sosiolinguistik Perkenalan Awal. Jakarta: PT Rineka Cipta

Depdiknas. 2011. Pedoman Umum Ejaan Bahasa Yang Disempurnakan dan Pedoman Umum Pembentukan Istilah. Bandung: Yrama Widya. 
Halliday, M.A.K. dan Hasan, Ruqaiya. 1994. Bahasa, Konteks, dan Teks. Diterjemahkan oleh: Asruddin Barori. Yogyakarta: Gadjah Mada University Press.

Hudson. R.A. 1995. Sosiolinguistics. Diterjemahkan oleh: Rochayah dan Misbach. Jakarta: Pusat Pembinaan dan Pengembangan Bahasa Departemen Pendidikan dan Kebudayaan.

Kridalaksana, Harimurti. 2007. Pembentukan Kata dalam Bahasa Indonesia. Jakarta: Gramedia.

Moleong, L.J. 2007. Metodologi Penelitian Kualitatif. Bandung: PT Remaja Rosdakarya.

Ramlan. 2009. Morfologi Suatu Tinjauan Deskriptif. Yogyakarta: CV Karyono.

Soeparno. 2002. Dasar-dasar Linguistik Umum. Yogyakarta: PT Tiara Wacana.

Sudaryanto.1988. Metode Linguistik bagaian pertama: Ke Arah Memahami Metode Linguistik. Yogyakarta : Gadjah Mada University Press.

Verhaar, J. 2006. Asas-asas Linguistik Umum. Yogyakarta: Gadjah Mada University Press 